\title{
Pengaruh Strategi Problem Based Learning (PBL) Terhadap Peningkatkan Hasil Belajar Pendidikan Kewarganegaraan (PKn) Siswa Sekolah Dasar
}

\author{
Bhakti Prima Findiga Hermutaqien \\ Universitas Negeri Makasar, Indonesia \\ bhakti@unm.ac.id
}

\begin{abstract}
ABSTRAK
Penelitian ini bertujuan mengetahui pengaruh peningkatan strategi pembelajaran Problem Based Learning (PBL) terhadap hasil belajar PKn siswa kelas V di SDN Sumber Porong 3 Lawang. Penelitian ini adalah penelitian kuantitatif dengan metode eksperimen. Populasi penelitian ini adalah siswa kelas 5 SDN Sumber Porong 3 Lawang yang berjumlah 50 siswa. Sampel penelitian ini berjumlah 25 siswa yang diambil secara acak menggunakan teknik simpel random sampling. Sampel dibagi dalam kelompok kontrol dan kelompok eksperimen. Teknik pengumpulan data penelitian ini menggunakan angket, observasi, dan test. Teknik analisis data penelitian ini menggunakan uji normalitas, homogenitas dan uji T. Hasil penelitian ini menunjukkan penerapan strategi PBL dapat meningkatkan hasil belajar PKn siswa kelas 5 SDN Sumber Porong 3 Lawang yang dilihat dari hasil uji T. Data tersebut menunjukkan perbedaan hasil belajar yang sangat signifikan antara kelas control dan kelas eksperimen dengan nilai sig. (2-tailed) adalah 0,000<0,05. Perbedaan juga dapat dilihat dari rata-rata nilai kelas dan ketuntasan klasikal yang diambil dari hasil post-test. Kelas eskperimen memiliki ketuntasan klasikal $100 \%$ dengan rata-rata nilai 90,75 dan kelas control memiliki ketuntasan klasikal 60\% dengan rata-rata nilai 71,96. Selisih perbedaan nilai rata-rata kedua kelas adalah 18,79 dan selisih ketuntasan adalah 40\%. Peningkatan hasil belajar siswa tidak hanya berasal dari siswa melainkan juga kinerja guru dalam pembelajaran yang didukung dengan kerjasama antar lembaga sekolah, kepala sekolah, guru dan orangtua dalam menyediakan sarana prasarana untuk mencapai hasil yang maksimal.
\end{abstract}

Kata kunci: Hasil Belajar, Number Head Together

\section{ABSTRACT}

Implementation Strategies Problem Based Learning (PBL) To Improve Results Learning Education Citizenship (Civics) Elementary School Student aims to determine the increase in the result of learning civics class $X$ after using PBL learning strategies in SDN Sumber Porong 3. This research is quantitative research with experimental methods. The population of this study was class V students of SDN Sumber Porong 3, which amounted to 50 students. The sample of this study amounted to 25 students taken randomly using a simple random sampling technique. Samples were divided into the control group and the experimental group. The data collection technique of this study uses questionnaires, observations, and tests. The data analysis technique of this study uses the normality, homogeneity and T test. The results of this study indicate the application of PBL strategies can improve civics learning outcomes of class X students of SDN Sumber Porong 3 Lawang seen from the results of the $T$ test. The data shows very significant differences in learning outcomes between the control class and the experimental class with the sig value. (2-tailed) is 0,000<0,05.Differences can also be seen from the average class scores and classical completeness taken from the results of the post-test. The experimental class has $100 \%$ classical completeness with an average score of 90,75 and the control class has $60 \%$ classical completeness with an average value of 71.96. The difference in the average value of the two classes is 18,79 and the difference in completeness is $40 \%$. Improving student learning outcomes not only comes from students but also the performance of teachers in learning which is supported by collaboration between school institutions, principals, teachers and parents in providing infrastructure to achieve maximum results.

Keywords: Problem based learning, Learning outcomes

\section{PENDAHULUAN}

Pengaruh strategi problem based learning (PBL) terhadap peningkatkan hasil belajar Pendidikan Kewarganegaraan (PKn) siswa sekolah dasar adalah penelitian yang bertujuan untuk melihat apakah terdapat pengaruh strategi problem based learning (PBL) terhadap peningkatkan hasil belajar Pendidikan Kewarganegaraan (PKn) siswa sekolah dasar.
Penelitian ini didasari oleh rendahnya hasil belajar PKn siswa sekolah dasar. Hasil belajar PKn siswa perlu ditingkatkan karena juga mengingat bahwa sekolah merupakan sarana dimana pendidikan dan pemahaman serta keterampilan siswa akan kewarganegaraan harus dibina dengan baik (Geboers, dkk, 2015). Pendidikan memiliki peran meningkatkan kualitas hidup yang akan berkontribusi bagi 
diri, bangsa dan negara seperti dengan pendidikan akan membawa siswa untuk melakukan suatu perubahan (Idris, dkk, 2012). Kegiatan mengajar atau mendidik ini harus mampu membuat siswa mengembangkan kemampuan kognitif, kemampuan dalam hidup bersosialisasi dan mengalami perubahan emosionalnya (Ezquerra, dkk, 2014).

Pembelajaran PKn yang baik adalah dengan membuat siswa menjadi aktif dalam pembelajaran. Keaktifan siswa dapat dipacu melalui pembauran dengan lingkungan tempat tinggal siswa guna melihat permasalahan yang mucul dilingkungan sekitar siswa, dengan kata lain PKn berorientasi pada masalah ditengah masyarakat (Saylor, 2016). Penelitian di AS menunjukkan bahwa adanya kesenjangan antara pengetahuan dan keterampilan siswa dalam pembelajaran PKn sehingga penelitian untuk meningkatkan pengetahuan dengan model pembelajaran kritis atau berbasis masalah perlu dilakukan pada siswa (Zohar \& Cohen, 2016). Adapun Permasalahan dalam pembelajaran PKn adalah banyaknya pembelajaran dengan teknik mengahafal dan keterlibatan serta keaktifan siswa dalam pembelajaran sangat rendah (Skubal, 2016). Model pembelajaran Problem Based Learning adalah model yang sesuai untuk memacu siswa berpikir kritis dan aktif dengan permasalahan dunia nyata (Rusman, 2011).

PKn merupakan pendidikan yang penting bagi perkembangan berpikir kritis siswa, keaktifan serta keterlibatan dalam kehidupan sosialnya (Willemse, dkk, 2015). PKn juga adalah pendidikan yang mengacu pada pengetahuan, keterampilan, serta memiliki tujuan membentuk siswa menjadi terampil, memiliki nilai-nilai, dan sikap yang baik serta dalam kegiatan pembelajaran menjadi menarik, kritis dan partisipatif (Nogueira, f., \& moreira, 2012). PKn harus menggunakan metode yang dapat meningkatkan cara berpikir siswa menjadi lebih kritis (Ahrari, dkk, 2016). Maka dalam pembelajaran PKn harus menggunakan strategi yang tepat.

Problem Based Learning (PBL) merupakan pembelajaran dimana siswa lebih aktif dalam pembelajaran dengan memecahkan permasalahan dunia nyata secara berkelompok, karena tujuan dari PBL adalah membuat siswa berpikir secara kritis dan belajar secara mandiri (İnel \& Balım, 2013). Model pembelajaran PBL mengintegrasikan berbagai konsep serta keterampilan dari berbagai disiplin ilmu dalam materi pembelajaran dan menuntut siswa aktif dalam pemecahan masalah (Komalasari, 2013). Dengan pembelajaran menggunakan strategi PBL dapat meningkatkan hasil belajar siswa dan keterampilan siswa (Gurses, dkk, 2015).

\section{METODE PENELITIAN}

Metode penelitian pada penelitian ini adalah metode true eksperimen dengan pendekatan kuantitatif eksplanasi. Objek dari penelitian ini adalah SDN Sumber Porong 3 Lawang dengan subjek penelitian siswa kelas $\mathrm{V}$ yang terdiri dari populasi berjumlah 50 siswa/i, sedangkan sampel pada penelitian ini berjumlah 25 siswa/i yang diambil menggunakan teknik simple random sampling. Pengumpulan data dengan observasi, angket, tes dan dokumentasi. Data yang telah dikumpulkan oleh peneliti dianalisis menggunakan bantuan aplikasi SPSS IBM 22.0 for windows dengan uji normalitas, homogenitas, dan uji independent sampel t-test.

\section{HASIL \& PEMBAHASAN}

Uji normalitas adalah uji yang dilakukan oleh peneliti untuk mengetahui sebaran data penelitian yang berasal dari populasi apakah merupakan sebaran yang normal atau tidak (Santoso, 2010). Adapun tujuan dari uji normalitas adalah untuk mengetahui variabel dari penelitian masingmasing berdistribusi normal dan tidaknya, selain itu tidak boleh ada penyimpangan jika ada maka uji tidak valid (Ghozali, 2013). Berdasarkan pengertian diatas maka peneliti melakukan uji normalitas pada variabel $X$ yaitu strategi PBL dan variabel Y yaitu Hasil Belajar untuk mengetahui apakah kedua variabel tersebut memiliki data yang berdistribusi normal atau tidak, sebagai syarat untuk melakukan uji selanjutnya yakni uji hipotesis. Hasil uji normalitas dapat dilihat pada tabel dibawah ini:

Tabel 1. Hasil uji normalitas

One-Sample Kolmogorov-Smirnov Test

\begin{tabular}{|c|c|c|}
\hline & Eksperimen & Control \\
\hline $\mathrm{N}$ & 25 & 25 \\
\hline Mean & 90,7576 & 71,2121 \\
\hline
\end{tabular}




\begin{tabular}{ll|r|r}
$\begin{array}{l}\text { Normal } \\
\text { Parameters }\end{array}$ & Std. Deviation \\
b & & 4,35194 & 6,25379 \\
Most & Absolute &, 259 & \\
Extreme & Positive &, 165 &, 273 \\
Differences & Negative &,- 259 &, 242 \\
& &, 259 &,- 273 \\
&, $000^{\mathrm{c}}$ &, 273 \\
Test Statistic & &, $000^{\mathrm{c}}$ \\
Asymp. Sig. (2-tailed)
\end{tabular}

Berdasarkan hasil uji normalitas diatas dapat dilihat bahwa hasil dari masing-masing kelas yakni kelas eksperimen adalah 0,259 dan kelas control adalah 0,273. Dilihat dari dasar pengambilan keputusan uji normalitas, hasil dari kedua kelas tersebut adalah nilai signifikansi lebih besar dari 0,05. Dari hasil tersebut maka peneliti menarik kesimpulan bahwa data berdistribusi normal.
Uji homogenitas adalah uji yang dilakukan untuk mengetahui apakah kedua kelompok sampel yang diambil dan diteliti dalam sebuah penelitian memiliki varians yang homogen atau tidaknya (Sudjana, 2016). Hasil uji homogenitas dapat dilihat pada tabel dibawah ini:

Tabel 2. Hasil Uji Homogenitas

Test of Homogeneity of Variances eksperimen

\begin{tabular}{|c|c|c|c|}
\hline Levene Statistic & df1 & df2 & Sig. \\
\hline 1,195 & 2 & 26 & ,319 \\
\hline
\end{tabular}

Berdasarkan hasil uji homogenitas pada tabel diatas diketahui bahwa nilai signifikansinya adalah 0,319. Dari dasar pengambilan keputusan diketahui bahwa jika nilai signifikansi hasil uji homogenitas $>0,05$ maka data kelompok sampel homogen. Dari hasil uji homogenitas diatas nilai signifikansi lebih besar maka peneliti dapat menarik kesimpulan bahwa kelompok sampel dalam penelitian ini bersifat homogen.

Uji independent sampel t-test adalah uji terhadap nilai satu variabel dan dilakukan bagi hipotesis deskriptif yang dimana hipotesis yang telah dibuat harus diuji (Sugiyono, 2015).
Adapun maksudnya adalah pengujian dilakukan untuk melihat apakah penerapan strategi PBL dapat meningkatkan hasil belajar atau tidak. Tujuan dari uji ini adalah untuk melihat apakah ada pengaruh penerapan strategi PBL terhadap hasil belajar PKn siswa kelas 5 SDN Sumber Porong 3 Lawang. Pengaruh tersebut dilihat dari perbedaan nilai hasil post-test dari kelas eksperimen yang mendapat treatment atau perlakuan dan kelas control yang tidak mendapat treatment, jika ada perbedaan yang signifikan maka terdapat pengaruh antara variabel X yakni Strategi PBL terhadap variabel $\mathrm{Y}$ yakni hasil belajar.

Tabel 3. Hasil Uji Independent Sampel t-test Independent Samples Test

\begin{tabular}{|c|c|c|c|c|c|c|c|c|c|c|}
\hline & \multicolumn{2}{|c|}{$\begin{array}{l}\text { Levene's } \\
\text { Test for } \\
\text { Equality of } \\
\text { Variances } \\
\end{array}$} & \multicolumn{7}{|c|}{ t-test for Equality of Means } \\
\hline & & \multirow[b]{2}{*}{$F$} & \multirow[b]{2}{*}{ Sig. } & \multirow[b]{2}{*}{$t$} & \multirow[b]{2}{*}{ df } & \multirow{2}{*}{$\begin{array}{l}\text { Sig. } \\
(2- \\
\text { taile } \\
\text { d) }\end{array}$} & \multirow{2}{*}{$\begin{array}{c}\text { Mean } \\
\text { Differen } \\
\text { ce }\end{array}$} & \multirow{2}{*}{$\begin{array}{c}\text { Std. } \\
\text { Error } \\
\text { Differen } \\
\text { ce }\end{array}$} & \multicolumn{2}{|c|}{$\begin{array}{l}95 \% \text { Confidence } \\
\text { Interval of the } \\
\text { Difference }\end{array}$} \\
\hline & & & & & & & & & Lower & Upper \\
\hline $\begin{array}{l}\text { VAR000 } \\
01\end{array}$ & $\begin{array}{l}\text { Equal } \\
\text { variances } \\
\text { assumed } \\
\text { Equal } \\
\text { variances } \\
\text { not } \\
\text { assumed }\end{array}$ & ,944 & ,335 & 14,737 & $\begin{array}{r}57,1 \\
05\end{array}$ &, 000 & $\begin{array}{r}19,5454 \\
5\end{array}$ & 1,32630 & $\begin{array}{r}16,895 \\
87\end{array}$ & 22,20122 \\
\hline
\end{tabular}


Berdasarkan hasil uji independent sampel t-test pada tabel diatas diketahui bahwa nilai sig. (2-tailed) adalah 0,000. Dari dasar pengambilan keputusan jika nilai signifikansi $\leq$ 0,05 artinya telah terdapat pengaruh antara variabel $\mathrm{X}$ terhadap Variabel Y dan dilihat dari nilai sig. (2-tailed) $0,000 \leq 0,05$. Dari hasil nilai signifikansi uji independent sampel t-test jelas dilihat nilai signifikansi lebih kecil dari 0,05 , maka peneliti dapat menarik kesimpulan bahwa terdapat perbedaan yang sangat signifikan antara kelas eksperimen dan kelas control, karena ada perbedaan yang signifikan maka penerapan strategi problem based learning (PBL) berpengaruh meningkatkan hasil belajar.

Ketuntasan atau keberhasilan belajar tidak hanya dilihat dari setiap individual siswa namun juga ketuntasan klasikal dalam suatu kelas. Ketuntasan klasikal suatu kelas jika jumlah Siswa/i yang mencapai KKM adalah $>85 \%$ (Sudjana, 2016). Hasil perhitungan ketuntasan klasikal dan nilai rata-rata kelas eksperimen dan kelas control dapat dilihat pada tabel berikut

Tabel 4. Perbandingan Nilai Rata-rata dan Ketuntasan Klasikal

\begin{tabular}{|c|c|c|}
\hline & Nilai Rata-Rata & $\begin{array}{c}\text { Ketuntasan } \\
\text { Klasikal }\end{array}$ \\
\hline Kelas Eksperimen & 90,75 & $100 \%$ \\
\hline Kelas Control & 71,96 & $60 \%$ \\
\hline
\end{tabular}

Dari tabel perbandingan nilai rata-rata dan ketuntasan klasikal diatas menunjukkan bahwa adanya perbedaan nilai antara kelas ekperimen dan kelas control. Selisih perbedaan nilai rata-rata antara kelas eksperimen dan kelas control adalah 18,79 dan selisih ketuntasan klasikal antara kelas eksperimen dan kelas control adalah $40 \%$. Dari selisih nilai kedua kelas tersebut peneliti dapat menarik kesimpulan bahwa kelompok eksperimen yang mendapat perlakuan memiliki tingkat keberhasilan dalam belajar yang lebih tinggi dari kelompok control yang tidak mendapat perlakuan. Hal ini menunjukkan bahwa dengan penerapan strategi problem based learning (PBL) dapat meningkatkan hasil belajar PPKn siswa kelas 5 SDN Sumber Porong 3 Lawang.

Hasil belajar siswa akan meningkat jika didalam pembelajaran guru menggunakan strategi pembelajaran yang inovatif (Mccabe, 2018). Strategi pembelajaran merupakan rancangan pembelajaran yang berisi konsep materi pembelajaran yang akan digunakan dengan menggunakan teknik pembelajaran yang membuat siswa menjadi lebih aktif (Hardan, 2014). Dengan pembelajaran menggunakan strategi $P B L$ dapat meningkatkan hasil belajar siswa dan keterampilan siswa (Gurses, dkk, 2015).

Berdasarkan hasil perhitungan peneliti terhadap hasil post-test yang diberikan kepada kelas eksperimen sebagai kelas yang mendapat perlakuan menunjukkan bahwa strategi PBL dapat meningkatkan hasil belajar PPKn siswa kelas X dengan presentase ketuntasan klasikal $100 \%$ dan nilai rata-rata kelas 90,75 . Sedangkan pada kelas control presentase ketuntasan klasikal $60 \%$ dengan nilai rata-rata 71,96 . Selisih perbedaan nilai rata-rata 18,79 dan selisih ketuntasan klasikal antara kelas eksperimen dan kelas control adalah $40 \%$. Hal ini menunjukkan bahwa adanya perbandingan hasil belajar dengan penerapan strategi PBL dan adanya peningkatan hasil belajar PKn setelah menggunakan strategi pembelajaran PBL pada siswa kelas 5 SDN Sumber Porong 3 Lawang.

Hasil perhitungan data penelitian ini juga dengan melakukan uji independent sampel t-test menggunakan bantuan aplikasi SPSS IBM 22.0 for windows untuk melihat apakah ada pengaruh penerapan strategi PBL terhadap hasil belajar PKn siswa kelas 5 SDN Sumber Porong 3 Lawang dengan perbedaan yang muncul pada hasil uji jika sig. (2-tailed) $<0,05$ maka ada pengaruh. Dari hasil independent sampel t-test diketahui bahwa nilai sig. (2-tailed) adalah 0,000 lebih kecil dari 0,05. Berdasarkan hasil tersebut maka peneliti menarik kesimpulan bahwa terdapat perbedaan yang sangat signifikan antara kelas eksperimen dan kelas control. Karena ada perbedaan yang signifikan maka penerapan strategi problem based learning (PBL) berpengaruh meningkatkan hasil belajar.

$P B L$ merupakan suatu konsep pembelajaran yang memuat permasalahanpermasalahan dunia nyata yang luas dan terbuka yang digunakan untuk menjelaskan makna dan manfaat dari pelajaran kepada peserta didik sehingga siswa mampu berpikir terampil dan kritis (Rusman, 2011). Berdasarkan teori tersebut dan pelaksaan 
penerapannya, peneliti mengangkat masalahmasalah nyata dan disesuaikan dengan materi pembelajaran yang disusun pada rencana pelaksanaan pembelajaran (RPP) untuk kelas yang mendapat perlakuan yaitu kelas eksperimen.

Tahapan atau sintaks pembelajaran dengan $P B L$ yang dijelaskan menurut (Arend, 2004) menyatakan bahwa pembelajaran dengan $P B L$ terdiri dari 5 fase yakni; 1) Memberikan orientasi tentang permasalahannya kepada siswa, 2) Mengorganisasikan siswa untuk meneliti, 3) Membantu investigasi mandiri dan kelompok, 4) mengembangkan dan mempresentasikan artefak dan exhibition, dan 5) Menganalisis dan mengevaluasi proses mengatasi masalah.

Pelaksanaan pembelajaran dilakukan sesuai dengan RPP yang telah disusun oleh peneliti yang terdiri dari kegiatan pendahuluan, kegiatan inti, dan kegiatan penutup. Kegiatan pendahuluan merupakan kegiatan awal dalam proses pembelajaran yang bertujuan membangkitkan semangat, motivasi dan perhatian siswa untuk berperan dan berpartisipasi aktif dalam kegiatan pembelajaran (Abdul, 2012). Dalam penelitian ini kegiatan pendahuluan dilakukan dengan salam, berdoa, absensi, memperhatikan kerapian kelas dan siswa, menyanyikan lagu nasional, yel-yel, dan apersepsi pembelajaran dengan tanya jawab, penyampaian tujuan, manfaat serta garis besar kegiatan pembelajaran.

Kegiatan inti merupakan kegiatan penting dari proses pembelajaran yang bertujuan untuk mencapai kompetensi dasar (KD) dengan adanya kegiatan yang dapat memberikan ruang bagi siswa untuk memperoleh pengalaman baru, menyampaikan ide gagasan baik secara lisan dan tulisan serta mengambil keputusan atau pembenaran (Abdul, 2012). Kegiatan inti pada penelitian ini terdiri dari siswa membentuk kelompok, orientasi masalah, pemecahan masalah, berdiskusi dalam kelompok, mencari informasi dan solusi untuk pemecahan masalah, mengkaji, presentasi, serta musyawarah dan mufakat. Adapun ice breaking disela kegiatan inti untuk membangkitkan semangat siswa.

Kegiatan penutup adalah kegiatan akhir dalam proses pembelajaran yang terdiri dari kegiatan merangkum dan menyimpulkan materi yang didapat dari pembelajaran, merefleksi aktivitas pembelajaran, pemberian umpan balik, penilaian, penugasan bagi siswa dan menyampaikan tindak lanjut (Abdul, 2012).
Pelaksanaan kegiatan penutup dalam penelitian ini adalah guru membantu siswa merefleksi hasil penyelidikan dan diskusi siswa, guru melakukan evaluasi pembelajaran dan memberi timbal balik berupa penjelasan akan solusi yang tepat berdasarkan teori, menarik kesimpulan bersama-sama akan pemecahan masalah, pemberian post test, menyampaikan kegiatan pembelajaran besok, berdoa dan memberikan salam penutup.

Pelaksanaan pembelajaran dengan strategi PBL pada penelitian ini adalah dengan membentuk siswa dalam kelompok yang terdiri dari 5 kelompok, memberikan permasalahan pada siswa dengan menayangkan video menggunakan proyektor, memotivasi siswa untuk memecahkan permasalahan yang ada, membimbing siswa untuk berdiskusi dan mencari informasi yang berkaitan dengan permasalahan, dan siswa diminta untuk berdiskusi mencari solusi akan permasalahan yang ada serta mengakaji kembali solusi yang mereka cari untuk mendapatkan solusi yang paling tepat.

Peneliti meminta siswa untuk memberikan solusi dengan alasan yang logis berdasarkan teori dan informasi yang telah dicari oleh siswa. Langkah selanjutnya siswa mempresentasikan hasil diskusi mereka didepan kelas dengan batas waktu yang sudah ditentukan, setelah kegiatan presentasi siswa bermusyawarah dan bermufakat untuk menentukan solusi yang paling tepat untuk penyelesaian masalah. Kegiatan diskusi maupun kegiatan musyawarah dilaksanakan dengan selingan ice breaking yang dipimpin oleh peneliti untuk membangkitkan semangat siswa. Setelah pengambilan keputusan akan solusi yang tepat peneliti melanjutkan kegiatan refleksi dan memberikan umpan balik dengan penjelasan akan materi dan solusi berdasarkan teori. Kegiatan penutup dilakukan dengan menarik kesimpulan bersama-sama dan pemberian posttest. Pengerjaan untuk post-test dilakukan sesuai dengan waktu yang sudah ditentukan.

\section{KESIMPULAN \& SARAN}

Problem Based Learning (PBL) dapat meningkatkan hasil belajar siswa menengah atas yang dapat dilihat dari hasil uji independent sampel t-test dengan nilai nilai sig. (2-tailed) adalah $0,000<0,05$ yang menyatakan ada perbedaan yang sangat signifikan antar kelas eksperimen dan kelas control, serta ketuntasan klasikal 100\% dengan rata-rata nilai 90,75 pada kelas eksperimen dan kelas control memiliki ketuntasan klasikal $60 \%$ dengan rata-rata nilai 
71,96. Penerapan strategi pembelajaran Problem Based Learning (PBL) untuk meningkatkan hasil belajar siswa dapat dilaksanakan dengan tujuh tahapan pokok yakni membentuk siswa dalam kelompok, menyajikan permasalahan dengan tayangan video, mencari informasi akan permasalahan, mencari dan menentukan solusi yang tetap menurut kelompok, mempresentasikan hasil diskusi, serta bermusyawarah dan bermufakat bersama untuk mengambil keputusan akan solusi yang paling tepat. Peneliti selanjutnya diharapkan dapat melihat kelemahan dari penelitian ini dan melanjutkan penelitian dengan mengacu pada penelitian ini namun lebih mengarah pada penerapan strategi PBL yang dapat meningkatkan moral siswa.

\section{DAFTAR PUSTAKA}

Abdul, G. (2012). Desain Pembelajaran. Jogjakarta: Ombak.

Ahrari, S., Samah, b. A., Hassan, m. S., Wahat, n. W., \& Zaremohzzabieh, Z. (2016). Deepening critical thinking skills through civic engagement in Malaysian higher education. Thinking Skills and Creativity (Vol. 22).

Arend, R. (2004). Learning to teach. Seventh edition. New York: mcgraw hill companies.

Ezquerra, A., De-Juanas, A., \& Ulloa, C. S. M. (2014). Teachers' Opinion about Teaching Competences and Development of Students' Key Competences in Spain. Procedia - Social and Behavioral Sciences, 116, 12221226.

https://doi.org/10.1016/j.sbspro.2014.01. 372

Geboers, E.Geijsel, F., Admiraal, W., Jorgensen, T., \& Dam, g. T. (2015). Education, Citizenship development of adolescents during the lower grades of secondary. Journal of Adolescence, 45, 89-97.

Ghozali, I. (2013). Aplikasi Analisis Multivariate Dengan Program SPSS. Edisi Ketujuh. Semarang: Badan Penerbit Universitas Diponegoro.

Gurses, A., Dogar, c., \& geyik, E. (2015). Teaching of the Concept of Enthalpy Using Problem Based Learning Approach. Procedia - Social and Behavioral Sciences, 197, 2390-2394.

Gurses, A., Dogar, C., \& Geyik, E. (2015). Teaching of the Concept of Enthalpy Using Problem Based Learning
Approach. Procedia - Social and Behavioral Sciences, 197(February), 2390-2394.

https://doi.org/10.1016/j.sbspro.2015.07. 298

Hardan, A. A. (2014). Language Learning Strategies: A General Overview. Procedia - Social and Behavioral Sciences, $\quad 106, \quad 1712-1726$. https://doi.org/10.1016/j.sbspro.2013.12. 194

Idris, F., Gill, S. K., Ya'acob, A., Awal, N. A. M., \& Hassan, Z. (2012). The Role of Education in Shaping Youth's National Identity. Procedia - Social and Behavioral Sciences, 59, 443-450. https://doi.org/10.1016/j.sbspro.2012.09. 299

İnel, D., \& Balım, A. G. (2013). Concept Cartoons Assisted Problem based Learning Method in Science and Technology Teaching and Students' Views. Procedia - Social and Behavioral Sciences, 93, 376-380. https://doi.org/10.1016/j.sbspro.2013.09. 206

Iskandar. (2009). Psikologi pendidikan: sebuah orientasi baru. CipayungCiputat: Gaung Persada (GP) Press.

Komalasari, K. (2013). Pembelajaran kontekstual: konsep dan aplikasi. Bandung: PT. Refika Aditama.

Mccabe, j. A. (2018). What Learning Strategies Do Academic Support Centers Recommend to Undergraduates. Journal of Applied Research in Memory and Cognition, 7(1), 143-153. Retrieved from http://ejournal.uajy.ac.id/14649/1/JURNAL.pdf

Nogueira, f., \& moreira, A. (2012). A framework for civic education teachers' knowloedge. Social and Behavioral, 47, 1179-1183.

Rusman. (2011). Model-model pembelajaran mengembangkan profesionalisme guru. Jakarta: PT. Raja Grafindo Persada.

Santoso, A. (2010). Studi Deskriptif Effect Size Penelitian-Penelitian Di Fakultas Psikologi Universitas Sanata Dharma. Jurnal Penelitian, 14(1), 1-17.

Saylor, e. E. (2016). Civic education in elementary grades: Promoting student engagement in an era of accountability. The Journal of Social Studies Research, 40(3), 245-247.

Skubal, s. A. (2016). Making civics count: Citizenship education for a new 
generation. The Journal of Social Studies Research, 40(1), 53-54.

Sudjana, N. (2016). Penilaian Hasil Proses Belajar Mengajar. Bandung: Rosdikarya.

Sugiyono. (2015). Metode penelitian kuantitatif, kualitatif dan kombinasi (Mix Methods). Bandung: CV. Alfabeta.

Willemse, T. M., ten Dam, G., Geijsel, F., van Wessum, L., \& Volman, M. (2015). Fostering teachers' professional development for citizenship education.
Teaching and Teacher Education, 49, 118-127. https://doi.org/10.1016/j.tate.2015.03.00 8

Zohar, A., \& Cohen, A. (2016). Large scale implementation of higher order thinking (HOT) in civic education: The interplay of policy, politics, pedagogical leadership and detailed pedagogical planning. Thinking Skills and Creativity, 21 , 85-96. https://doi.org/10.1016/j.tsc.2016.05.003 